\title{
The Prevalence of Stroke Survivors in Urban Slums in Enugu, Nigeria
}

\author{
Oluchi Stella Ekenze', Ezeala-Adikaibe Birinus Adikaibe ${ }^{1,2 *}$, Onodugo Obinna ${ }^{1}$, Chime Peter ${ }^{2}$, \\ Orjioke Casmir ${ }^{2}$, Onodugo Pauline Nkiruka1, Mbadiwe Nkeiruka1, Onyekonwu Chinwe ${ }^{1}$, \\ Ijoma Nkemdilim Uchenna ${ }^{1}$, Okoye Julius Uwabunkeonye ${ }^{1}$, Obumneme-Anyim Ijeoma Nnenne ${ }^{3}$, \\ Ekochin Fintan², Ernest Okwundu Nwazor ${ }^{4}$, Emmanuel Uzodimma Iwuozo ${ }^{5}$
}

\author{
${ }^{1}$ Department of Medicine, University of Nigeria Teaching Hospital, Enugu, Nigeria \\ ${ }^{2}$ Department of Medicine, Enugu State University of Science and Technology Teaching Hospital, Enugu, Nigeria \\ ${ }^{3}$ Department of Pediatrics, University of Nigeria Teaching Hospital, Enugu, Nigeria \\ ${ }^{4}$ Department of Medicine, Federal Medical Center, Owerri, Nigeria \\ ${ }^{5}$ Federal Medical Center, Makurdi, Nigeria \\ Email: ^birinusadikaibe@gmail.com
}

How to cite this paper: Ekenze, O.S., Adikaibe, E.-A.B., Obinna, O., Peter, C., Casmir, O., Nkiruka, O.P., Nkeiruka, M., Chinwe, O., Uchenna, I.N., Uwabunkeonye, O.J., Nnenne, O.-A.I., Fintan, E., Nwazor, E.O. and Iwuozo, E.U. (2019) The Prevalence of Stroke Survivors in Urban Slums in Enugu, Nigeria. Open Journal of Preventive Medicine, 9, 51-67.

https://doi.org/10.4236/ojpm.2019.96006

Received: May 29, 2019

Accepted: June 27, 2019

Published: June 30, 2019

Copyright $\odot 2019$ by author(s) and Scientific Research Publishing Inc. This work is licensed under the Creative Commons Attribution International License (CC BY 4.0). http://creativecommons.org/licenses/by/4.0/

\section{Open Access}

\begin{abstract}
Background: Stroke is one of the commonest non-communicable diseases and the commonest cause of death in adult neurology wards. Stroke prevalence in sub Saharan Africa has dramatically increased over the past decades possibly due to changing life styles, poverty, poor health infrastructures which had led to increased risk factors for stroke. Poor nutrition and lack of access to standard medical care, predispose to high rates of stroke morbidity and mortality hence possible low prevalence. Little is known about the prevalence of stroke in people with low socio-economic status in Nigeria. Objectives: The main objective of this study was to determine the prevalence of stroke in two urban slums in south east Nigeria. Materials and Methods: This was a cross sectional descriptive study carried out in two slums in Enugu, South East Nigeria. Participants were screened using a stroke specific questionnaire and further examined by two independent neurologists for evidence of focal neurological deficits. Analysis was done by SPSS version 22. Results: A total of 1440 participants were surveyed in the study; 769 (53.4) females and 671 (46.6\%) males. About 22.3\% (321) screened positive for various neurological diseases out of which 17 (5.3\%) had evidence for stroke giving an overall prevalence of $1.2 \%$ (males 9 (1.3\%) vs females 8 (1\%) p = $0.6)$. The mean age of stroke survivors was 60.1 years, similar in males and females $(p=0.6)$. The odds ratio for stroke from 40 years showed progress increment doubling between 60 and 70 years and tripled between 40 and 70 years. Age, lower level of education, positive history of hypertension, sickle
\end{abstract}


cell disease, leg swelling and use of snuff positively are correlated with clinical diagnosis of stroke. Conclusion: The prevalence of stroke in two urban slums in Enugu metropolis was 12/1000. Hypertension, diabetes, use of snuff, and low levels of education were significant risk factors for stroke. Public health educational measures, promoting prevention and early detection of diabetes should be encouraged.

\section{Keywords}

Stroke, Prevalence, Nigeria

\section{Introduction}

Stroke is one of the commonest non-communicable diseases (NCDs) and the commonest cause of death in adult neurology wards [1] [2] [3] [4]. Stroke prevalence in sub Saharan Africa (SSA) has dramatically increased over the past decades [5] [6] possibly due to changing life styles, poverty, poor health infrastructures which had led to increased risk factors for stroke. Stroke is also one of the most devastating cardiovascular complications of hypertension and diabetes in Africa occurring at relatively younger ages [1] [3] [4] [7] [8] with a huge burden on SSA communities [9] [10].

The prevalence rates of stroke in SSA vary widely [10] [11]. In Nigeria, earlier studies by Osuntokun et al. [12] [13] documented low prevalence rates while recent studies have revealed increased prevalence rates [14] [15] [16] [17] [18]. An incidence of 1.14/1000 was reported by Danesi et al. [14]. Hospital-based studies in Nigeria show that stroke accounts for $64.9 \%-77.6 \%$ of neurological admissions [1] [2] [3] [4] [9]. This rising prevalence of stroke in Nigeria also reflects the high prevalence of hypertension, diabetes, HIV/AIDS and other risk factors for stroke in the community [19] [20] [21] [22]. The relationship between stroke, (major risk factors for stroke) and socioeconomic status has been documented [23] [24]. Most slum dwellers are likely to fall into this group [25]. Poor nutrition and lack of access to standard medical care predispose these individuals to high rates of stroke morbidity and mortality hence possible low prevalence. Little is known about the prevalence of stroke in people with low socio-economic status in Nigeria.

The study aims at finding the prevalence of stroke in two urban slums in south east Nigeria.

\section{Method}

This study was carried out in Agu-Abor and Ugbodogwu, two slums in Enugu, the capital of Enugu State, South East Nigeria. Both settlements occupy the foot of Udi hills and are about $2.5 \mathrm{~km}$ from the city center. They have an estimated population of 7000 - 9000. (This based on church and local records). The study design of this study has been published elsewhere [21] [22]. A three-phase 
cross-sectional descriptive study was carried out to survey at least $10 \%$ of the adult population (i.e. 700 - 800 adults based on the estimated adult population) who have lived in the area for at least 1 year. The study was divided into three phases. The first phase was sensitization of the population through churches, community awareness announcements on the streets and meeting(s) on the selected day(s). The second phase participants were visited at home by teams of research assistants. In this phase, the WHO STEPS instrument [26] was used to collect data on selected sociodemographic characteristics and lifestyle behaviors including physical activity. The World Health Organization (WHO) Protocol for Epidemiological studies in developing countries was used to screen for neurological disease [27]. The third phase of the study was done in a field clinic in Aguabor. Participants who screened positive for neurologic disease were further assess using a stroke specific questionnaire [15] and then examined by two independent neurologists for evidence of focal neurological deficits.

Stroke was defined as a clinical syndrome of rapidly progressive symptoms and signs of focal or global neurological deficit lasting more than twenty-four hours of which there is no apparent cause other than vascular origin, and/or past medical history stroke diagnosed by qualified personnel (doctors). Other clinical symptoms of patients were defined based on clinical description and or diagnosis by a medical doctor. Hypertension and diabetes were defined based on medical history and use of appropriated medications for treatment. Current tobacco use was defined as the use of any form of tobacco in the past 4 weeks. Alcohol use and quantity was defined as (mean number of days) the consumption of any alcoholic beverage in a week.

Artisans were defined as skilled manual laborers. Level of education was the individual's highest educational (formal) attainment based on the Nigerian school system. The study was conducted between August 2013 and December 2013.

SPSS version 23 (IBM Corporation, New York, USA) was used for data entry and analysis. For database management and statistical analyses, we used the SPSS version 20 (IBM Corporation, New York, USA). Data were presented in tables. For continuous variables, mean values and standard deviations were calculated. Prevalence of stroke was expressed as percentages. Mean values were compared using the independent t-test. In all, $\mathrm{p}$ values of $<0.05$ were regarded as statistically significant. The confidence level was kept at $95 \%$.

\section{Results}

A total of 1440 participants were surveyed in the study, this was made up of 769 females and 671 males (p-value $<0.001$ ) with a male to female ratio of 1:0.9. The mean age of the subjects was $44.9( \pm 15.2)$ years. There were no significant differences between the mean age of males and females (females $43.6 \pm 14.7$ versus males $45.3 \pm 15.3$, p value 0.44$)$. The age distribution of the subjects is shown in Table 1 . Most of them were young, less than 40 years (914/1440 (63.5\%)), engaged in business and at least secondary/tertiary education. 
Table 1. Characteristics of participants.

\begin{tabular}{|c|c|c|c|c|}
\hline Characteristic & Women & Men & Total & p-value ${ }^{x}$ \\
\hline \multicolumn{5}{|l|}{ Anthropometrics } \\
\hline Gender, n (\%) & $769(53.4)$ & $671(46.6)$ & $1440(100)$ & $<0.001$ \\
\hline Age, years mean (sd) & $34.8(13.6)$ & $39.1(16.1)$ & $36.8(14.8)$ & $<0.001$ \\
\hline \multicolumn{5}{|l|}{ Age group, $\mathrm{n}(\%)$} \\
\hline $20-29$ & $358(58.4)$ & $255(41.6)$ & $613(31.9)$ & \\
\hline $30-39$ & $166(55.1)$ & $135(44.9)$ & $301(20.9)$ & \\
\hline $40-49$ & $120(56.1)$ & $94(43.9)$ & $214(14.9)$ & \\
\hline $50-59$ & $64(45.7)$ & $76(54.3)$ & $140(9.7)$ & \\
\hline $60-69$ & $38(33.9)$ & $74(66.1)$ & $112(7.8)$ & \\
\hline$\geq 70$ & $23(38.3)$ & $37(61.7)$ & $60(4.2)$ & \\
\hline \multicolumn{5}{|l|}{ Occupation n (\%) } \\
\hline Students/apprentices & $235(30.6)$ & $184(27.4)$ & $419(29.1)$ & \\
\hline Artisans & $45(5.9)$ & $111(16.5)$ & $156(10.8)$ & \\
\hline Business & $302(39.3)$ & $156(23.2)$ & $458(31.8)$ & \\
\hline Civil servants/teachers & $64(8.3)$ & $89(13.3)$ & $153(10.6)$ & \\
\hline Retired/unemployed/others & $59(7.7)$ & $83(12.2)$ & $142(9.9)$ & \\
\hline Farmers & $64(8.3)$ & $48(7.2)$ & $112(7.8)$ & \\
\hline \multicolumn{5}{|l|}{ Level of Education n (\%) } \\
\hline None/primary & $190(24.7)$ & $178(26.5)$ & $368(25.6)$ & \\
\hline Secondary and above & $579(75.3)$ & $493(73.4)$ & $1072(74.3)$ & \\
\hline Lifestyle n (\%) & - & - & - & - \\
\hline Cigarette & $9(1.2)$ & $76(11.3)$ & $85(5.9)$ & $<0.001$ \\
\hline Snuff & $56(7.3)$ & $126(18.8)$ & $182(12.6)$ & $<0.001$ \\
\hline Current marijuana use (smoked) & $4(0.5)$ & $17(2.5)$ & $21(1.5)$ & 0.001 \\
\hline Alcohol use/week, n (\%) & - & - & - & - \\
\hline None & $374(48.6)$ & $220(32.8)$ & $594(41.3)$ & - \\
\hline $1-3$ & $331(43)$ & 268)39.9) & $599(41.6)$ & - \\
\hline $4-6$ & $40(5.2)$ & $124(18.5)$ & $164(11.4)$ & - \\
\hline 7 or more & $24(3.1)$ & $59(8.8)$ & $83(5.8)$ & - \\
\hline Medical history n (\%) & - & - & - & - \\
\hline Hypertension & 89 (11.6) & $68(10.1)$ & $157(10.9)$ & \\
\hline Diabetes & $21(2.7)$ & $30(4.5)$ & $51(3.5)$ & \\
\hline Stroke & $12(1.6)$ & $14(2.1)$ & $26(1.8)$ & \\
\hline Sickle cell disease & $5(0.7)$ & $2(0.3)$ & $7(0.5)$ & \\
\hline Leg swelling & $26(3.4)$ & $33(4.9)$ & $59(4.1)$ & \\
\hline Facial swelling & $11(1.4)$ & $10(1.5)$ & $21(1.5)$ & \\
\hline
\end{tabular}

\subsection{Lifestyle and Medical History}

About $12.6 \%$ and $5.9 \%$ of the subjects used snuff and smoked cigarettes. The proportion of tobacco users was significantly higher among males ( $p>0.001)$. A small number of the subjects used marijuana. About $5.8 \%$ of the subjects drank alcohol at least daily but the majority 599 (41.6) drank less than 3 days in a week. 
Medical history revealed that $10.9 \%$ reported a history of hypertension, $3.5 \%$ diabetes and $26(1.8 \%)$ reported a history of stroke. Seven $(0.5 \%)$ had a medical history of sickle cell disease (see Table 1 ).

\subsection{Demography of Those Who Had Stroke}

Three hundred and twenty-one participants $(22.3 \%)$ screened positive for various neurological disease in the stage 2 of the study based on the study protocol (Figure 1). Out of this 17 (5.3\%; 9 males and 8 females) had evidence for stroke giving an overall prevalence of $1.2 \%$ (12 per 1000). The mean age of stroke survivors was 60.1 years, similar in males and females $(p=0.6)$. The distribution of stroke survivors is shown in Table 2. The highest prevalence was recorded from 70 years and above (10\%), in those with hypertension (3.8\%), diabetes (7.8\%) and leg swelling (8.5\%) (Table 2).

\subsection{Factors Associated with Stroke}

The prevalence of stroke and odds ratio for stroke is shown in Table 3. The odds ratio for stroke from 40 years and above showed progress increment. It doubled between 60 and 70 years and tripled between 40 and 70 years. Sickle cell disease had the highest odds ratio recorded in the study. Age, lower level of education, positive history of hypertension, sickle cell disease, leg swelling and use of snuff positively correlated with clinical diagnosis of stroke (Table 4).

\section{Discussion}

This study has revealed a modest (12/1000) prevalence of stroke in an urban slum in Enugu Metropolis which did not vary between males and females. Though stroke prevalence in this study was highest after 70 years (100/1000) the prevalence of stroke was also relatively high between the ages of 40 - 49 (23/1000). Stroke rates above 12/1000 were recorded in individuals with lower educational status (41/1000), hypertension (38/1000), diabetes (78/1000), snuff users $(33 / 1000)$

\section{Positive screening for neurologic disorders}

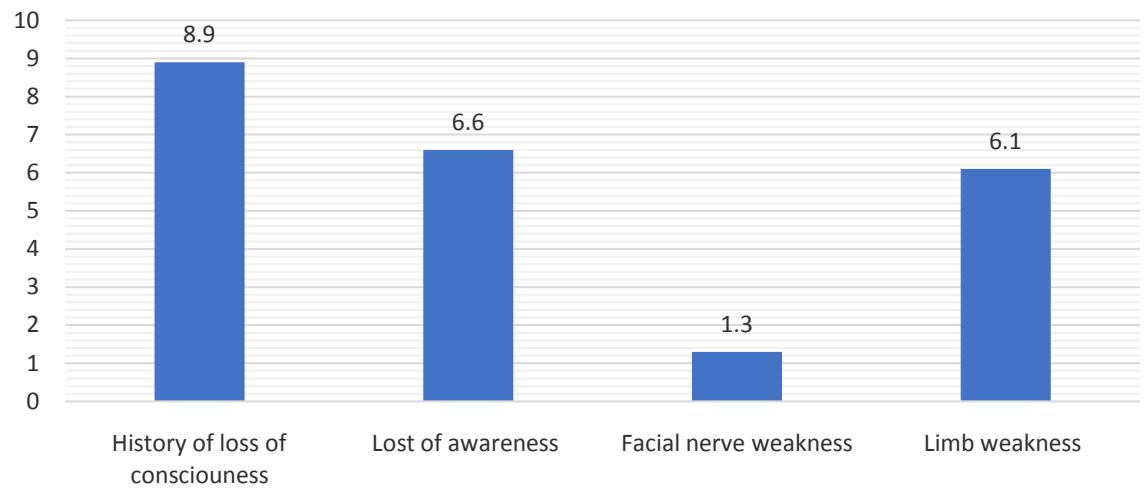

Figure 1. Frequency of severe neurologic disorders in the community. 
Table 2. Prevalence of stroke.

\begin{tabular}{|c|c|c|c|c|}
\hline & Women & Men & Total & p-value ${ }^{*}$ \\
\hline Gender, n (\%) & $8(1)$ & $9(1.3)$ & $17(1.2)$ & 0.6 \\
\hline \multicolumn{5}{|l|}{ Age Group n (\%) } \\
\hline $20-29$ & - & - & - & \\
\hline $30-39$ & - & - & - & \\
\hline $40-49$ & $3(2.5)$ & $2(2.1)$ & $5(2.3)$ & 0.86 \\
\hline $50-59$ & $1(1.6)$ & $3(3.9)$ & $4(2.9)$ & 0.4 \\
\hline $60-69$ & $1(2.6)$ & $1(1.4)$ & $2(1.8)$ & 0.63 \\
\hline$\geq 70$ & $3(13)$ & $3(11.1)$ & $6(10)$ & 0.54 \\
\hline \multicolumn{5}{|l|}{ Occupation n (\%) } \\
\hline Students/apprentices & - & - & - & - \\
\hline Artisans & - & $2(1.8)$ & $2(1.3)$ & 0.37 \\
\hline Business & $5(1.7)$ & - & $5(1.1)$ & 0.11 \\
\hline Civil servants/teachers & - & $1(1.1)$ & $1(0.7)$ & 0.4 \\
\hline Farmers & $1(1.6)$ & $1(2.1)$ & $2(1.8)$ & 0.84 \\
\hline Retired, unemployed/others & $2(3.4)$ & $5(6)$ & $7(4.9)$ & 0.48 \\
\hline \multicolumn{5}{|l|}{ Level of Education n (\%) } \\
\hline None/primary & $8(4.2)$ & $7(3.9)$ & $15(4.1)$ & \\
\hline Secondary and above & - & $2(0.4)$ & $2(0.2)$ & \\
\hline Lifestyle n (\%) & - & - & - & \\
\hline Current tobacco use, $\mathrm{n}(\%)$ & - & - & - & \\
\hline Snuff & $1(1.8)$ & $5(4)$ & $6(3.3)$ & 0.45 \\
\hline Current marijuana use (smoked) & - & - & - & \\
\hline Alcohol use/week, n (\%) & - & - & - & - \\
\hline Not drinking & $5(1.3)$ & $1(0.5)$ & $6(1)$ & 0.3 \\
\hline $1-3$ & $2(0.6)$ & $7(2.6)$ & $9(1.5)$ & 0.05 \\
\hline $4-6$ & $1(2.5)$ & - & $1(1.2)$ & 0.08 \\
\hline 7 or more & - & $1(1.7)$ & & \\
\hline Medical History n (\%) & - & - & - & - \\
\hline Hypertension & $3(3.4)$ & $3(4.4)$ & $6(3.8)$ & 0.74 \\
\hline Diabetes & $2(9.5)$ & $2(6.7)$ & $4(7.8)$ & 0.71 \\
\hline Sickle cell disease & $1(20)$ & - & $1(14.3)$ & 0.5 \\
\hline Leg swelling & $2(7.7)$ & $3(9.1)$ & $5(8.5)$ & 0.85 \\
\hline
\end{tabular}

${ }^{*} \mathrm{p}$-values are for the sex differences.

Table 3. Odds ratio for stroke in the community.

\begin{tabular}{cccc}
\hline & Prevalence of stroke (\%) & Odds ratio $(95 \% \mathrm{CI})$ & p-value \\
\hline Age $\geq 40$ years & 3.2 & $1.03(1.02-1.05)$ & $<0.001$ \\
$\geq 50$ years & 3.8 & $8.98(3.14-25.7)$ & $<0.001$ \\
$\geq 60$ years & 4.7 & $6.82(2.6-17.93)$ & $<0.001$ \\
$\geq 70$ years & 10 & $13.83(4.93-38.7)$ & $<0.001$ \\
$\quad$ Snuff & 3.3 & $2.98(0.35-25.17)$ & 0.005 \\
Hypertension & 3.8 & $4.6(1.68-12.6)$ & 0.001 \\
\hline
\end{tabular}




\section{Continued}

\begin{tabular}{cccc}
\hline Diabetes & 7.8 & $9.01(2.83-28.67)$ & $<0.001$ \\
Sickle cell disease & 14.3 & $14.75(1.68-129.65)$ & 0.001 \\
Leg swelling & 8.5 & $10.55(3.59-31)$ & $<0.001$ \\
Tobacco use (including smoking) & 2.3 & $2.48(0.91-6.75)$ & 0.07 \\
\hline
\end{tabular}

Table 4. Correlation statistics for stroke in the communities.

\begin{tabular}{cc} 
Variable & $\begin{array}{c}\text { Correlation statistic } \\
\mathrm{r}(\mathrm{p} \text {-value })\end{array}$ \\
\hline Age & $0.01(0.4)$ \\
\hline Level of education $(1$ primary or less, 2 higher than primary $)$ & $0.14(<0.001)^{*}$ \\
History of hypertension $(1=$ yes, $0=$ no $)$ & $-0.16(<0.001)$ \\
History of diabetes $(1=$ yes, $0=$ no $)$ & $0.09(0.001)^{*}$ \\
History of sickle cell disease $(1=$ yes, $0=$ no $)$ & $0.12(<0.001)^{*}$ \\
History of leg swelling $(1=$ yes, $0=$ no $)$ & $0.09(0.001)^{*}$ \\
History of facial swelling $(1=$ yes, $0=$ no $)$ & $0.14(<0.001)^{*}$ \\
Snuff $(1=$ yes, $0=$ no $)$ & $-0.01(0.61)$ \\
Alcohol/week $(0=$ none, $1=1-3$ drinks, $2=4-6$ drinks, & $0.08(<0.01)$ \\
$3=7$ or more days $)$ & $0.04(0.87)$
\end{tabular}

and leg swelling (85/1000). These variables also demonstrated a positive correlation with stroke. Other interesting findings are the steep rise in the odds of having stroke after 50 years which dropped after 60 years.

Studies reveal an increasing prevalence rate of stroke in SSA. Early studies by Osuntokun et al. [12] [13] found a community prevalence of 58 - 400/100,000, a crude annual mortality rate of about 700/100,000 per year and age specific mortality in the elderly of about 100/100,000 per year while more recent studies have reported higher rates [17] [18]. The increasing prevalence of stroke is clearly related to increasing rates of cardiovascular and metabolic disorders which were rare in the early and middle decades of the last century [20] [21] [22] [28] [29]. Related to this is are high rates of HIV/AIDS, smoking and alcohol abuse as well as poor healthcare infrastructure and public health educational strategies [30] [31] [32] [33] [34]. Related to these are high rates of alcohol and tobacco use as well as increasing use of amphetamines and cocaine [30]. Surveys from other African countries have also reported increasing prevalence of stroke [35] [36] [37] [38].

The prevalence of stroke in the index study is within the reported global prevalence and continental of 4 and 20 per 1000 population [10] [11] [37] [38] [39] [40] with higher rates among people with socioeconomic status [38] [39] [40] [41] [42]. Poor health facilities, lack of access to care, high cost as well as inherent risky cultural practices/beliefs among the urban poor may coalesce in high 
rates of mortality leading to low prevalence. Other factors include low health insurance coverage in the country, poor health infrastructure (with few if any functional emergency stroke services) as well as lack of neurologists/stroke specialists. The stroke burden in south-east Nigeria and especially in urban slums may be therefore affected by these multifaceted factors. Basic stroke evaluation tools such as radio-imaging, echo studies as well blood investigations are available but remain out of reach of most patients. Furthermore, the non-existent stroke educational programs which should form the basis for any meaningful community based preventive programs is also contributory. Studies have shown that low cost strategies such as public educational programs produce attitudinal change [43]. Results from the index may be explained not only by population specific characteristics (age distribution in favor of the young, the area surveyed (urban slum)) but also on methodological issues. Most studies from the continent used WHO criteria similar to the index study.

Several traditional risk factors for stroke such as older age, hypertension and diabetes were reported in the present study. Stroke is relatively more common in young Africans and the peak age has been shown to be lower in Africans compared to their Caucasian counterparts [7] [8]. The age specific rates of stroke and the mean age of stroke survivors are similar to findings from both epidemiological and hospital-based studies from Nigeria and SSA. Slightly different findings from earlier studies [10] may suggest a paradigm shift in the age of stroke occurrence among Africans as an increasing number of the population are surviving to old age. This will definitely increase the burden of stroke in the country. There is need for strict and effect health policies to reduce the modifiable risk factors for stroke and thereby reduce its overall burden.

Significant independent risk factors for stroke in this study included the use of snuff. In South-East Nigeria the use of snuff is widely accepted in the community more than cigarette smoking hence it is widespread in most communities. Snuff (mostly homemade) likely contains lots of tobacco specific nitrosamines which have been implicated in predisposing to cardiovascular diseases [44] [45]. Earlier studies did not find an excess risk of stroke with smokeless tobacco [44], however, there are some evidence that smokeless tobacco may be associated with an increased risk of fatal ischemic stroke and myocardial infarction [46] [47].

Other risk factors for stroke like alcohol use and cigarette smoking are very common in many Nigerian communities [33] [34]. These substances were not significant risk for stroke in the index study probably because we surveyed the rates of current use rate than lifetime use of these substances. The prevalences of hypertension and diabetes in the index communities have been previously documented [21] [22]. The overlapping impact of low socio-economic status and these factors may contribute to high rates of stroke severity and mortality. Poor health seeking behavior and lack of health insurance schemes with consequent out of pocket funding of medical expenses may all be contributory. Lower life expectancy and possibly higher stroke fatality rates in poor communities might present with "false" low prevalence rate of stroke. 
We found a positive association between stroke and lower level of education in the index study which was also is similar to the report by Amarenco et al. [48] who observed that low level of education, unemployment status and low quality of living were predictive of major vascular events. People in low level of education are more likely to earn less and affected by factors discussed earlier. Furthermore, factors such as poor nutrition and use substances such as alcohol and tobacco may also be contributory. People with low levels of education are less likely to understand and apply health related behavioral changes that may be disseminated by public health workers. The relationship between leg welling and stroke is not very clear as we did not explore the causes of this symptoms. However, leg swelling is a cardinal symptom of heart failure, immobility and renal failure with are in turn risk factors for stroke.

\section{Limitations of the Study}

This study has some limitations. First, we did not account for stroke mortality which might lead to low prevalence rates. The age and gender distribution of the population might have skewed our findings to the lower end of the spectrum because of the high proportion of young people in the study. The diagnosis of stroke was limited to history and clinical diagnosis instead of neuro imaging. The study did not find out the exact time of the stroke and hence could not ascertain the time lapse before a possible repeat stroke.

\section{Conclusion}

The prevalence of stroke in an urban slum in Enugu metropolis was 12/1000 and is within the range previously reported but higher than the current studies in Nigeria. Hypertension, diabetes, use of snuff, and low levels of education were significant risk factors for stroke. Public health educational measures, promoting prevention and early detection of diabetes should be encouraged. Efforts should be made to educate the populace on the need for early detection and treatment.

\section{Acknowledgements}

We acknowledge the leaders of Agu-Abor and Ugbodogwu communities for their support, and to Miss Loveth Emmanuel, Secretary, Neurology and EEG services, Mount Carmel Hospital Enugu, for her help in the office.

\section{Funding}

The project described was supported by the Medical Education Partnership Initiative in Nigeria (MEPIN) project funded by Fogarty International Center, the Office of AIDS Research, and the National Human Genome Research Institute of the National Institute of Health, the Health Resources and Services Administration (HRSA) and the Office of the US Global AIDS Coordinator under Award Number R24TW008878. The content is solely the responsibility of the authors and does not necessarily represent the official views of the funding organiza- 
tions.

\section{Conflicts of Interest}

The authors declare no conflict of interest.

\section{References}

[1] Obiakor, O.R., Opara, S.K. and Oguniyi, A. (2011) Prognosis and Outcome of Acute Stroke in the University College Hospital Ibadan, Nigeria. Nigerian Journal of Clinical Practice, 14, 359-362. https://doi.org/10.4103/1119-3077.86784

[2] Ezeala-Adikaibe, B.A., Aneke, E., Orjioke, C., Ezeala-Adikaibe, N.P., Mbadiwe, M., Chime, P., et al. (2014) Pattern of Medical Admissions at Enugu State University of Science and Technology Teaching Hospital: A 5-Year Review. Annals of Medical and Health Science Research, 4, 426-431.

[3] Ekenze, O.S., Onwuekwe, I.O. and Ezeala Adikaibe, B.A. (2010) Profile of Neurological Admissions at the University of Nigeria Teaching Hospital Enugu. Nigerian Journal of Medicine, 19, 419-422. https://doi.org/10.4314/njm.v19i4.61967

[4] Eze, C.O. and Kalu, U.A. (2014) Pattern of Neurological Admissions in the Tropics: Experience at Abakaliki South-Eastern Nigeria. Journal of Biology, Agriculture and Healthcare, 4, 84-86.

[5] Osuntokun, B.O. (1971) The Pattern of Neurological Illness in Tropical Africa. Experience at Ibadan, Nigeria. Journal of the Neurological Sciences, 12, 417-442. https://doi.org/10.1016/0022-510X(71)90110-9

[6] Ojini, F.I. and Danesi, M.A. (2003) The Pattern of Neurological Admissions at the Lagos University Teaching Hospital. Nigerian Journal of Clinical Practice, 6, 38-41.

[7] Ogun, S.A., Ojini, F.I., Ogungbo, B., Kolapo, K.O. and Danesi, M.A. (2005) Stroke in South West Nigeria: A 10-Year Review. Stroke, 36, 1120-1122. https://doi.org/10.1161/01.STR.0000166182.50840.31

[8] Owolabi, L.F. and Ibrahim, A. (2012) Stroke in Young Adults: A Prospective Study from Northwestern Nigeria. ISRN Neurology, 2012, Article ID: 468706. https://doi.org/10.5402/2012/468706.

[9] Moran, A., Forouzanfar, M., Sampson, U., Chugh, S., Feighin, V. and Mensah, G. (2013) The Epidemiology of Cardiovascular Diseases in Sub-Saharan Africa: The Global Burden of Diseases, Injuries and Risk Factors 2010 Study. Progress in Cardiovascular Diseases, 56, 234-239. https://doi.org/10.1016/j.pcad.2013.09.019

[10] Adeloye, D. (2014) An Estimate of the Incidence and Prevalence of Stroke in Africa; a Systematic Review and Meta-Analysis. PLOS ONE, 9, e100724.

https://doi.org/10.1371/journal.pone.0100724

[11] Owolabi, M., Olowoyo, P., Popoola, F., Lackland, D., Jenkins, C., Arulogun, O., et al. (2018) The Epidemiology of Stroke in Africa: A Systematic Review of Existing Methods and New Approaches. The Journal of Clinical Hypertension, 20, 47-55. https://doi.org/10.1111/jch.13152

[12] Osuntokun, B., Bademosi, O., Akinkugbe, O., Oyediran, A. and Carlisle, R. (1979) Incidence of Stroke in an African City: Results from the Stroke Registry at Ibadan, Nigeria, 1973-1975. Stroke, 10, 205-207. https://doi.org/10.1161/01.STR.10.2.205

[13] Osuntokun, B.O., Adeuja, A.O., Schoenberg, B.S., et al. (1987) Neurological Disorders in Nigerian Africans: A Community-Based Study. Acta Neurologica Scandinavica, 75, 13-21. https://doi.org/10.1111/j.1600-0404.1987.tb07883.x 
[14] Danesi, M., Okubadejo, N. and Ojini, F. (2007) Prevalence of Stroke in an Urban, Mixed-Income Community in Lagos, Nigeria. Neuroepidemiology, 28, 216-223. https://doi.org/10.1159/000108114

[15] Enwereji, K.O., Nwosu, M.C., Ogunniyi, A., Nwani, P.O., Asomugha, A.L., et al. (2014) Epidemiology of Stroke in a Rural Community in Southeastern Nigeria. Vascular Health and Risk Management, 2014, 375-388. https://doi.org/10.2147/VHRM.S57623

[16] Onwuchekwa, A.C., Tobin-West, C. and Babatunde, S. (2014) Prevalence and Risk Factors for Stroke in an Adult Population in a Rural Community in the Niger Delta, South-South Nigeria. Journal of Stroke and Cerebrovascular Diseases, 23, 505-510. https://doi.org/10.1016/j.jstrokecerebrovasdis.2013.04.010

[17] Ezejimofor, M.C., Uthman, O.A., Maduka, O., Ezeabasili, A.C., Onwuchekwa, A.C., et al. (2017) Stroke Survivors in Nigeria: A Door-to-Door Prevalence Survey from the Niger Delta Region. Journal of the Neurological Sciences, 372, 262-269. https://doi.org/10.1016/j.jns.2016.11.059

[18] Sanya, E.O., Desalu, O.O., Adepoju, F., Aderibigbe, S.A., Shittu, A. and Olaosebikan, O. (2015) Prevalence of Stroke in Three Semi-Urban Communities in Middle-Belt Region of Nigeria: A Door to Door Survey. Pan African Medical Journal, 20, 33. https://doi.org/10.11604/pamj.2015.20.33.4594

[19] Ezeala-Adikaibe, B.A., Aneke, E., Orjioke, C., Okafor, H.U., Ezeala-Adikaibe, N.P. and Mbadiwe, N. (2018) Neurological Admissions at Enugu State University Teaching Hospital: A 5-Year Retrospective Review. Journal of Experimental Research, 6, 1-10.

[20] Ezeala-Adikaibe, B., Mbadiwe, N., Orjioke, C., Aneke, E., Chime, P. and Okafor, H. (2014) Estimated Probability of Stroke among Medical Outpatients in Enugu South East Nigeria. Annals of Medical and Health Science Research, 4, 879-883.

[21] Ezeala-Adikaibe, B.A., Orjioke, C., Ekenze, O.S., Ijoma, U., Onodugo, O., Okudo, G., et al. (2015) Population-Based Prevalence of High Blood Pressure among Adults in an Urban Slum in Enugu, South East Nigeria. Journal of Human Hypertension, 30, 285-291. https://doi.org/10.1038/jhh.2015.49

[22] Ezeala-Adikaibe, B.A., Mbadiwe, N., Okwara, C., Onodugo, O., Onyekonwu, C., Ijoma, U., et al. (2018) Diabetes and Pre-Diabetes among Adults in an Urban Slum in South East Nigeria. Journal of Diabetes Mellitus, 8, 131-144.

https://doi.org/10.4236/jdm.2018.84013

[23] Grimaud, O., Dufouil, C., Alpérovitch, A., Pico, F., Ritchie, K.A., Helmer, C., et al. (2011) Incidence of Ischaemic Stroke According to Income Level among Older People: The 3C Study. Age and Ageing, 40, 116-121.

https://doi.org/10.1093/ageing/afq142

[24] Krishnan, S., Cozier, Y.C., Rosenburg, L. and Palmer, J. (2010) Socioeconomic Status and Incidence of Type 2 Diabetes: Results from the Black Women's Health Study. American Journal of Epidemiology, 171, 564-570. https://doi.org/10.1093/aje/kwp443

[25] Forouhi, N.G., Luan, J., Hennings, S. and Wareham, N.J. (2007) Incidence of Type 2 Diabetes in England and Its Association with Baseline Impaired Fasting Glucose: The Ely Study 1990-2000. Diabetic Medicine, 24, 200-207. https://doi.org/10.1111/j.1464-5491.2007.02068.x

[26] WHO (2005) WHO STEPwise Approach to Chronic Disease Risk Factor Surveillance (STEPS). WHO, Geneva, Switzerland.

[27] Osuntokun, B.O., Schoenberg, B.S., Nottidge, V.A., Adeuja, A., Kale, O., Adeyefa, 
A., et al. (1982) Research Protocol for Measuring the Prevalence of Neurological Disorders in Developing Countries. Results of a Pilot Study in Nigeria. Neuroepidemiology, 1, 143-153. https://doi.org/10.1159/000110696

[28] Yamane, T. (1967) Statistics, an Introductory Analysis. 2nd Edition, Harper and Row, New York.

[29] Okafor, C.I. (2012) The Metabolic Syndrome in Africa: Current Trends. IIndian Journal of Endocrinology and Metabolism, 16, 56-66. https://doi.org/10.4103/2230-8210.91191

[30] Integrated Biological and Behavioural Surveillance Survey (IBBSS) (2014) National HIV/AIDS \& STIS Control Programme. Federal Ministry of Health, Nigeria.

[31] Aliyu, S.U., Chiroma, A.S., Jajere, A.M. and Gujba, F.K. (2015) Prevalence of Physical Inactivity, Hypertension, Obesity and Tobacco Smoking: A Case of NCDs Prevention among Adults in Maiduguri, Nigeria. The American Journal of the Medical Sciences, 3, 39-47.

[32] Lasebikan, V.O. and Ola, B.A. (2016) Prevalence and Correlates of Alcohol Use among a Sample of Nigerian Semirural Community Dwellers in Nigeria. Journal of Addiction Medicine, 2016, Article ID: 2831594. https://doi.org/10.1155/2016/2831594

[33] Adewuya, A.O., Ola, B.A., Aloba, O.O., Mapayi, B.M., Ibigbami, O.I. and Adewumi, T.A. (2007) Alcohol Use Disorders among Nigerian University Students: Prevalence and Sociodemographic Correlate. Nigerian Journal of Psychiatry, 5, 5-9. https://doi.org/10.4314/njpsyc.v5i1.39893

[34] Lasebikan, V.O., Ayinde, O., Odunleye, M., Adeyefa, B., Adepoju, S., Fakunle, S., et al. (2018) Prevalence of Alcohol Consumption and Alcohol Use Disorders among Outdoor Drinkers in Public Open Places in Nigeria. BMC Public Health, 18, 400. https://doi.org/10.1186/s12889-018-5344-6

[35] Venketasubramanian, N., Tan, L.C.S., Sahadevan, S., Chin, J.J., Krishnamoorthy, E.S., Hong, C.Y., et al. (2005) Prevalence of Stroke among Chinese, Malay, and Indian Singaporeans: A Community-Based Tri-Racial Cross-Sectional Survey. Stroke, 36, 551-556. https://doi.org/10.1161/01.STR.0000155687.18818.13

[36] Feigin, V.L., Lawes, C.M., Bennett, D.A. and Anderson, C.S. (2003) Stroke Epidemiology: A Review of Population-Based Studies of Incidence, Prevalence and Case-Fatality in the Late 20th Century. The Lancet Neurology, 2, 43-53. https://doi.org/10.1016/S1474-4422(03)00266-7

[37] Agyemang, C., Attah-Adjepong, G., Owusu-Dabo, E., De-Graft Aikins, A., Addo, J., Edusei, A.K., et al. (2012) Stroke in Ashanti Region of Ghana. Ghana Medical Journal, 46, 12-17.

[38] Engels, T., Baglione, Q., Audibert, M., Viallefont, A., Mouriji, F. and Faris, M.A. (2014) for GRAVCM Study Group. Socioeconomic Status and Stroke Prevalence in Morocco: Results from the Rabat-Casablanca Study. PLoS ONE, 9, e89271. https://doi.org/10.1371/journal.pone.0089271

[39] Wu, S.H., Woo, J. and Zhang, X.-H. (2013) Worldwide Socioeconomic Status and Stroke Mortality: An Ecological Study. International Journal for Equity in Health, 12, 42. http://www.equityhealthj.com/content/12/1/42 https://doi.org/10.1186/1475-9276-12-42

[40] Sposato, L.A. and Grimaud, O. (2013) Neighborhood Socioeconomic Status and Stroke Mortality. Neurology, 80, 516-517. https://doi.org/10.1212/WNL.0b013e3182815564

[41] Addo, J., Ayerbe, L., Mohan, K.M., Crichton, C., Sheldenkar, A., Chen, R., et al. 
(2012) Socioeconomic Status and Stroke an Updated Review. Stroke, 43, 1186-1191. https://doi.org/10.1161/STROKEAHA.111.639732

[42] Kapral, M.K., Wang, H., Mamdani, M. and Tu, J.V. (2002) Effect of Socioeconomic Status on Treatment and Mortality after Stroke. Stroke, 33, 268-275. https://doi.org/10.1161/hs0102.101169

[43] Ajzen, I. (1991) The Theory of Planned Behavior. Organizational Behavior and Human Decision Processes, 50, 179-211. https://doi.org/10.1016/0749-5978(91)90020-T

[44] Asplund, K. (2001) Snuff: How Dangerous Is It? The Controversy Continues. Journal of Internal Medicine, 250, 457-461. https://doi.org/10.1046/j.1365-2796.2001.00918.x

[45] Asplund, K., Nasic, S., Janlert, U. and Stegmayr, B. (2003)Smokeless Tobacco as a Possible Risk Factor for stroke in Men A Nested Case-Control Study. Stroke, 34, 1754-1759. https://doi.org/10.1161/01.STR.0000076011.02935.A1

[46] Boffetta, P. and Straif, K. (2009) Use of Smokeless Tobacco and Risk of Myocardial Infarction and Stroke: Systematic Review with Meta-Analysis. British Medical Journal, 339, b3060. https://doi.org/10.1136/bmj.b3060

[47] SCENIHR (Scientific Committee on Emerging and Newly-Identified Health Risks) (2008) Scientific Opinion on the Health Effects of Smokeless Tobacco Products. European Commission, Brussels.

[48] Amarenco, P., Abboud, H., Labreuche, J., Arauz, A., Bryer, A., Lavados, P.M., et al. (2014) Impact of Living and Socioeconomic Characteristics on Cardiovascular Risk in Ischemic Stroke Patients. International Journal of Stroke, 9, 1065-1072. https://doi.org/10.1111/ijs.12290 


\section{Appendix}

This work is designed to find out how many people at Agu-Abor and Ugboodogwu have disorders that affect the nervous system. Your identity will not be disclosed to anyone or released for any other purpose except for the goal of this study without your permission.

Thank you for cooperating with us.

General information

Initials.

Age

Occupation.

House number Phone/phone of next of kin

Place of origin. State. Tribe LGA. Town Village

Past medical history

Previous hospitalizations Yes No Reasons.

History of head injury Yes No

With loss of consciousness... Yes No without loss of consciousness Yes No

Have you been told that you have/ had

- Hypertension

- Diabetes

- Stroke

- Epilepsy

- Asthma

- Sickle cell disease

Which other "sickness" are you suffering from?

Please if you have of had convulsions or up rolling of the eyes associated with fever

Yes No

Please if you have of had up rolling of the eyes not associated with fever

Yes No

History of convulsion/episodic up rolling of the eyes in the family

Yes No

History of (suspected) mental illness

Yes No

Have you had brain surgery in the past

Yes No

please describe-

Obstetric history (for children less than 11 years).

Number in the family (including all pregnancies)

Mother's illness during pregnancy.

Duration of pregnancy.... months

Type of delivery. SVD......

Eclampsia (convulsion and high blood pressure during pregnancy) Yes No 


\section{Labour for (this present child)}

Normal Prolonged Yes No

place of delivery

home maternity hospital

church other places ------

Labour (delivery) Assisted delivery

Yes No

Type (describe).........

Postpartum

Illness........ Type (convulsions) (fever) (diarrhea) (pneumonia) (Jaundice)

Others describe

Developmental milestones

Normal... Yes No

Delayed... Yes

No

Immunization history. completed Yes No

Missed immunizations......

Total number of immunizations......

Family and social history.

Illnesses in the family.

$\begin{array}{llr}\text { Hypertension } & \text { Yes } & \text { No } \\ \text { Stroke } & \text { Yes } & \text { No } \\ \text { Leg swelling } & \text { Yes } & \text { No } \\ \text { Chronic cough } & \text { Yes } & \text { No } \\ \text { Type asthma } & \text { tuberculosis } \\ \text { others (describe) } & & \end{array}$

\section{USE OF TOBACCO}

Do smoke or use snuff (in any form)

Yes

No

Type

Cigarette

Yes

Snuff

Yes

No

Marijuana

Yes

No

Others (describe)-glue-cocaine-(etc.) ASK!

Do smoke or use snuff (in any form)

Yes

No

Yes

No

Type

Cigarette Yes

No

Snuff

Yes

No

Marijuana

Yes

No

Others (describe)-glue-cocaine (etc.)

Do you drink alcohol Yes

What type of alcohol

Beer 
Gin

Stout

Local

What quantity do you think you consume in a week

Drug History.

Do you know the names of the drugs you are taking now at home

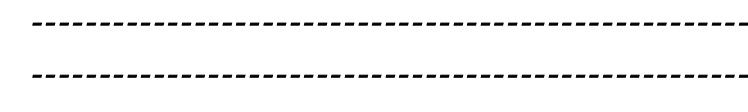
Where do you normally get your drugs from

$\begin{array}{lcc}\text { Market } & \text { Yes } & \text { No } \\ \text { Pharmacy } & \text { Yes } & \text { No } \\ \text { Chemist } & \text { Yes } & \text { No } \\ \text { Hospital } & \text { Yes } & \text { No } \\ \text { Maternity } & \text { Yes } & \text { No } \\ \text { SCREENING INSTRUMENTS. } & \end{array}$

\section{Part 1}

Q1 Have you ever lost consciousness?

Q2 Have you ever had episodes where you lost contact with your surroundings?

Q3 Have you ever had episodes of shaking of your arms or legs which you could not control?

Q4 Is your speech normal?

Q5 Have you had episodes of pain in the face?

Q6 Has your face or part of your face ever been paralyzed even for few minutes?

Q7 Have you ever had weakness in your arms or legs paralyzed even for few minutes?

Q8 Have you been unable to walk properly?

Q9 Have you ever had loss of sensation or abnormal sensation affecting your arms and legs paralyzed even for few minutes?

Q10 Have you ever suffered from headache?

Q11 Do you suffer from severe headaches, chiefly on one side of the head, which come on from time to time?

Q12 In association with these headaches, do you suffer from visual disturbances: e.g. black spots or zigzag lines in front of your eyes?

Q13 In association with these headaches, do you suffer from nausea or vomiting?

Q14 In association with these headaches, do you suffer from weakness or numbness in the limbs that lasts less than a few days?

Q15 Do these headaches occur only when you have a febrile illness?

Q16 Do you have problems with remembering recent events?

Part 2. 
E1 Hold both arms above head for $30 \mathrm{~s}$.

E2 Pick up matchstick from ground.

E3 Close your eyes. Feel cloth sample. Is it smooth or rough?

E4 Put your hands out in front of you. Close your eyes. Touch your nose with the right index. Repeat it using your left.

E5 Walk heel to toe along the white line (distance of one meter).

E6 Stand with both feet together.

E7 Close your eyes and stand still for $15 \mathrm{~s}$ (only if able to perform). 